IRA-International Journal of Management \&

Social Sciences

ISSN 2455-2267; Vol.12, Issue 03 (September 2018)

Pg. no. 55-61.

Institute of Research Advances

http://research-advances.org/index.php/RAJMSS

Institute of

\title{
The Role of ECOWAS on Peace and Conflict Resolution in Nigeria and Gambia
}

\author{
Isaac Terungwa Terwase ${ }^{1 \#}$, Olubukola S. Adesina ${ }^{2}$, Gloria Samdi Puldu ${ }^{3}$, Asmat- \\ Nizam Abdul-Talib ${ }^{1}$ \\ ${ }^{1}$ Universiti Utara Malaysia, Kedah State, Malaysia. \\ ${ }^{2}$ Department of Political Science, University of Ibadan, Nigeria \\ ${ }^{3}$ Department of Political Science, University of Jos, Nigeria.
}

\#corresponding author.

Type of Review: Peer Reviewed.

DOl: http://dx.doi.org/10.21013/jmss.v12.n3.p1

\section{How to cite this paper:}

Terwase, I.T., Adesina, O.S., Puldu, G.S., Abdul, A. (2018). The Role of ECOWAS on Peace and Conflict Resolution in Nigeria and Gambia. IRA-International Journal of Management \& Social Sciences (ISSN 2455-2267), 12(3), 55-61. doi:http://dx.doi.org/10.21013/jmss.v12.n3.p1

(C) Institute of Research Advances.

\section{(cc) BY-NC}

This work is licensed under a Creative Commons Attribution-Non Commercial 4.0 International License subject to proper citation to the publication source of the work.

Disclaimer: The scholarly papers as reviewed and published by the Institute of Research Advances (IRA) are the views and opinions of their respective authors and are not the views or opinions of the IRA. The IRA disclaims of any harm or loss caused due to the published content to any party.

Institute of Research Advances is an institutional publisher member of Publishers International Linking Association Inc. (PILA-CrossRef), USA. The institute is an institutional signatory to the Budapest Open Access Initiative, Hungary advocating the open access of scientific and scholarly knowledge. The Institute is a registered content provider under Open Access Initiative Protocol for Metadata Harvesting (OAI-PMH).

The journal is indexed \& included in WorldCat Discovery Service (USA), CrossRef Metadata Search (USA), WorldCat (USA), OCLC (USA), Open J-Gate (India), EZB (Germany) Scilit (Switzerland), Airiti (China), Bielefeld Academic Search Engine (BASE) of Bielefeld University, Germany, PKP Index of Simon Fraser University, Canada. 


\begin{abstract}
This paper examines the issues that led to political conflicts in Nigeria and Gambia. The paper further explains the role ECOWAS played in the past in sustaining peace and security in the West African regional community. ECOWAS has been able to conduct peacekeeping in countries such as Liberia, Sierra Leon, and Coted'Ivoire. The methodology used is qualitative design. The work also used published works and internet sources for the purpose of data collection. The findings revealed that, the political conflict between the North and South led to increased security threats by the Boko Haram in Nigeria. In Gambia, the actions of President Jammeh who initially accepted election result, knowing that he was defeated and later rejected the outcome of the elections which led to apolitical conflict. Therefore, the paper recommends early warning mechanism to be employed in handling issues that may result into conflict.
\end{abstract}

Keywords: ECOWAS, Nigeria, Gambia, Peace and Conflict Resolution.

\title{
INTRODUCTION
}

The West African regional body was established in 1975 with the aim of integrating the regional community in the area of commerce, trade and industry for the purpose of developing the region economically (Terwase, Abdul-Talib, \& Zengeni, 2015). The regional body, Economic Community of West African States (ECOWAS) subsequently shifted from the economic focus to more broad areas such as political fields in relation to Conflict prevention, conflict management, and conflict resolution (Francis, 2009). On these bases, ECOWAS has played vital roles in conflict management and resolution within the West African sub-region.

There are countries where the ECOWAS regional body participated actively in resolving political conflict through peacekeeping operations in countries such as Sierra Leone, Liberia, Guinea-Bissau, and Cote d'Ivoire (Adeleke, 1995; Gershoni, 1997; Francis, 2009; Bah, 2010). This motivation was engineered by the West African countries such as Nigeria, Guinea, Ghana, Sierra Leone, and The Gambia, which formed the ECOWAS Monitoring Group(ECOMOG) which was established on the $6^{\text {th }}-7^{\text {th }}$ of August, 1990 during the meeting of the ECOWAS in the Gambia's capital city of Banjul(Adibe, 1997). ECOWAS deployed a military intervention in Liberia on the $24^{\text {th }}$ of August, 1990 through her peacekeeping force known as ECOMOG (Inegbedion, 1994). The ECOWAS leadership in 1990 led by General Ibrahim Babangida of Nigeria deployed the ECOMOG to peacekeeping operations in the Liberian civil war.

Political conflict as seen in Liberia was not the last conflict in the West African sub-region. Cote d'Ivoire also witnessed political conflict. However, the essence of this work is to look at the two countries under study in this paper which basically concerns the role of ECOWAS on peace and conflict in Nigeria and The Gambia. In the case of Nigeria, the country witnessed political conflict from 2010 to 2015. The Boko Haram attacks against the Nigerian State did not stop in 2015, considering the fact that they even occupied about 14 Local Government Areas in Nigeria from the North-Eastern States of Borno, Adamawa and Yobe respectively. The conflict was said to be geared up by the power sharing agreement within the country between the North and South geo-political zones. Ofuatey-Kodjoe (1994) observed that Nigeria played an aggressive role in establishing ECOWAS as well as playing key roles in the peace and security sustenance of the West African regional body.

More so, the country Nigeria became engulfed with political crisis as a result of the activities of the Boko Haram insurgency, it was this insurgency which started attacks on the country in 2009 during the President Yar'Adua's led government. The President who was Yar'Adua laterdied and the Vice-President; Goodluck Jonathan took over power as enshrined by the Nigerian constitution of 1999. President Jonathan assumed power as the country's leader on the $6^{\text {th }}$ of May, 2010. This work would examine the political conflict therein which also had religious undertone as well as regional dimension.In the case of the Gambia's political conflict which was bloodless, the work would also examine the role played by ECOWAS in resolving the conflict.

\section{OBJECTIVES OF THE STUDY}

The objectives of the study are to examine the following: 
1) To assess issues that geared up the Boko Haram conflict in Nigeria as a member of ECOWAS

2) To examine the role played by ECOWAS in resolving the conflict.

3) To examine the role of ECOWAS in resolving the Gambia's Political conflict in 2016-2017.

4) To proffer measures in addressing conflict prevention in the West African regional block.

\section{FINDINGS AND DISCUSSIONS}

Firstly, the paper looks at the issues that engineered the Nigeria's political conflict and assessed the role of ECOWAS in addressing the conflict.

\section{1) The Truncated Zoning Arrangements:}

The work of Ololajulo (2016) argues that the principle of zoningpolitical offices was a mechanism or tool in balancing the ethno-religious conflict that may emanate from the country's major ethnic groups such as the HausaFulani, Igbo and Yoruba; as well as the two major religious identities in Nigeria known as the Christians and the Muslims. Nigeria was formerly ruled by the Military over time before the return of the democratic rule in 1999 which ushered in the civilian take-over of power. Terwase, Abdul-Talib, \& Zengeni (2015) observed that Nigeria during the return of power from the military rule in 1999, practiced the zoning arrangement which could also be referred to as rotation of power between the North and South over a period of time. The work further explains that, the Southern part of the country ruled from 1999 to 2003 and 2003 to 2007, a total period of eight years which were four year term each.

Awopeju, Adelusi\&Oluwashakin (2012) in their work, examined how the country's presidency was rotational based on the agreements within the then ruling political party known as the People's Democratic Party (PDP). This was not based on the Nigeria's constitutional powers but on an agreement within the PDP to foster the power sharing formula between the North and South for a period of eight years each. Ezeibe, Abada\&Okeke (2016) explained that, after the death of President Yar'Adua, a Northerner, and another Southerner took over power in the person of President Jonathan. The 2011 general elections which led to President Jonathan's nomination as the PDP party bearer in the general elections created tension in Northern Nigeria as well as bringing in the truncated zoning arrangements within the party (Terwase, Yerima, Abdul-Talib \& Ibrahim 2016).

Oshewolo (2013) argues that the late National Security Advisor to President Jonathan noted that, the 2011 general elections that brought in President Jonathan's leadership of Nigeria from 2011-2015 led to increased violence in Nigeria. The work further explained that more Nigerians were killed in the Northern part of the country making Nigeria a state of insecurity and politically unstable due to the attacks by the Boko Haram. Agbiboa\&Maiangwa (2013) agree that Boko Haram sect became sophisticated and coordinated in their attacks against the Nigerian State which increased bombing of worship centers such as that of St. Theresa's Catholic Church in Madala, as it claimed lives of about 27 people on the $25^{\text {th }}$ of December, 2011. The work of Aliyu (2013) noted that the Late Andrew Azazi had allegedly argued that Boko Haram were being sponsored by some senior members of the then ruling political party, the PDP. Ademowo (2015) connotes that, the Late General Azazi's comments on Boko Haram summarizes their activities as influence from political quarters while blaming the security agencies of their inability to suppress the insurgents.

Udounwa (2013) opined that the country's security infrastructure needed a build-up considering the fact that the country's security forces do not have adequate weapons to fight the Boko Haram insurgents. The country's security budget was increased in 2012 becoming the largest amount ever spent on Nigeria's security. Agbiboa (2013) argued that the realities of poverty and economic deprivation such as unemployment are considerably serious issues on why the youths join the Boko Haram sect to work for them in attacking the Nigerian state especially from the Northern part of the country where the group originated from. The Boko Haram attacks continued till the tenure of President Jonathan was over in 2015 and he was equally defeated in the 2015 presidential elections that took place. After he left office as the President, a new President, Bahari took over power on the 29h of May, 2015. His administration was able to recapture the 14 Local Government Areas that were formerly taken over by the Boko Haram. 


\section{2) The Role of ECOWAS on Peace and Conflict Resolution in Nigeria:}

The work of Onuoha (2014) acknowledged that, Boko Haram sect is a security threat to the members of the ECOWAS regional group. As such, ECOWAS adopted a strategy to stop terrorism within the region. Boko Haram which originally started her attacks in Nigeria, later spread to other countries such as Chad, Niger and Cameroon(Onapajo,Uzodike\&Whetho, 2012). Niger Republic is a member of the ECOWAS community. ECOWAS adopted the Political Declaration and Common Position against Terrorism in 2013. The work further explained that, the regional counter terrorism strategy and an Implementation Plan is to help the regional group in countering all forms of terrorist activities in the region. The work noted that Nigeria remains a giant in the security architecture of the West Africa regional community.

Secondly, the paper examines the role of ECOWAS in resolving the Gambia's political conflict.

\section{1) The Long Term Leadership of President Yahya Jammeh:}

The political conflict in Gambia became pronounced in December, 2016 after the democratic elections that took place in the country's presidential elections. President Yahya Jammeh, a long serving leader in office as the president of The Gambia from 1994 to $21^{\text {st }}$ of January, 2017 became the country's second leader after succeeding Dawda Jawara who ruled from the inception of the country's independence in 1965. President Yahya Jammeh, organized the elections that led to his defeat on the $1^{\text {st }}$ of December, 2016. When the result was announced by the Gambia's electoral body, President Jammeh at first accepted the results and he conceded defeat which was widely accepted by the international community and had applauded Jammeh (The Guardian, 21 December, 2016).

In that election, the people voted for the opposition leader Adama Barrow. The President-elect, Adama Barrow was forced to leave on exile considering the political conflict between the two political leaders. This took place on the $9^{\text {th }}$ of December, 2016 when President Yahya Jammeh turned to say, he no longer accepted the outcome of the December $1^{\text {st }}, 2016$ result which he initially accepted its outcome. At that stage, the ECOWAS stepped in to assist the country in resolving the political crisis which could have claimed the lives of many Gambians.

\section{2) The Role of ECOWAS on Peace and conflict resolution:}

The ECOWAS regional community comprised leaders from Nigeria, Ghana, Senegal, Liberia, Guinea, and Sierra Leon who united to resolve the political conflict in Gambia. ECOWAS standby force was also involved in the peace and conflict resolution of the Gambia's political crisis. On the advice of the ECOWAS regional group, Presidentelect, Adama Barrow fled to Senegal where he stayed, and was officially sworn in to office as the country's president in Gambia's Embassy, Senegal with theECOWAS Standby Force comprising the ECOWAS Armed Forces from Nigeria, Senegal, Ghana and Sierra Leon. President Yahya Jammeh finally agreed and stepped down as President of the Gambia under the mediation of the ECOWAS leaders. More so, the new President Adama Barrow returned to Gambia from Senegal after the former President, Yahya Jammeh went on exile (The Guardian, 21 January, 2017).

\section{CONCLUSIONS}

The role of ECOWAS on peace and conflict resolution in the West Africa sub-region has greatly improved the stability of the region considering the fact that, conflict issues such as political, economic, social and identity crisis occurs from time to time. Through ECOWAS leadership, countries such as Liberia, Gambia, Sierra Leon, Guinea and Cote d'Ivoire witnessed resolution on issues that led to such conflicts. This paper concludes that, early warning mechanism should always be used in preventing further occurrences on bloody conflicts and war in West Africa.

\section{RECOMMENDATIONS}

This research work recommends measures that can be taken to prevent future occurrences as well as to resolve the current situations in some countries.

\section{Provision of Employment for the Youths:}


The youths are mostly used during the state of war in carrying arms against the government and innocent souls. Some of the youths who involve themselves in carrying arms are unemployed. They do not have any source of livelihood which makes them available for such acts as well as being used by the sponsors as the case maybe. Measures can then be taken by the government to create more jobs through private-public partnerships.

Through the sectors that may be neglected in countries where mono-economy is practiced, diversification of the economy should be employed. An example is that, some countries have neglected their tourism industry, to some mining, while some the development of their agricultural sector, such sectors should be developed so as to create more jobs for the youths. When the youths are gainfully employed, they will have something doing which would make them unavailable to carrying arms and killing innocent people.

\section{Early warning mechanism should be employed:}

In some cases, before conflict could break-up, some governments in African States do not take pre-cautions in averting issues that could lead to conflict. As such, they neglect issues at the very beginning during agitations and when such issues are not addressed, it may transform into war. Therefore, all issues that are raised through agitations should be taken into due consideration on how such could be addressed in order to prevent conflicts between the agitators and the government. This is done through the early warning mechanism system. Where early warning is neglected, the people suffer a lot especially when innocent people are being killed and the country turns into a state of political instability.

Addressing issues through the early warning mechanism also preserves the country's stability and as such, could promote peace and security sustainability where international business could also strive peacefully. There is need for African leaders to develop a comprehensive early warning mechanism system so as to create consciousness among the people and the governments of African States.

\section{Regional Integration through Sub-Regional Blocks:}

In Africa, there are regional blocks such as Economic Community of West African States (ECOWAS), Southern African Development Community (SADC), East African Community (EAC), and Arab Maghreb Union (AMU), these regional bodies can also apply the early warning mechanism within their sub-regions so as to put the countries within the region to look into issues that are raised through agitations at the very beginning before they could transform from conflict to war which may affect international business within the region.

The work of Terwase, Abdul-Talib \& Zengeni (2014) observed similar issues such as agitations, which, when they are taken into consideration at the early stage, could prevent further conflicts that may occur. African leaders through the regional blocks should have one voice that would sustain peace and security sustainability. The researcher observed that, ECOWAS has played an effective role in the past in building and sustaining peace and security through their diplomatic ties in resolving conflicts in countries such as Mali, Liberia, Ivory Coast, and Sierra Leon. Such resolution of conflict promotes peaceful environments where international businesses could strive.

\section{Rural-Urban Infrastructure Development:}

The roads in the rural areas need to be developed, most of the African people living in the rural areas are farmers and when they produce goods as products from their farm lands, such products should be transported effectively to the urban centers for the purpose of turning it into finished goods. As such, the government through private-public partnership should engage in developing both the rural and urban communities in the area of infrastructural development.

Again, more industries can be sited in the rural areas where the raw materials abound and in some cases are being wasted. The international businessmen and multinational companies can also look into this direction where the rural communities envisage tapping the natural resources that are found therein. Another dimension is employing rural electrification within African rural communities so as to develop the said areas. This will promote business activities where raw materials are found in such communities. Notwithstanding, the urban centers too need adequate attention 
in developing the infrastructure such as health systems, constructing good roads, providing school facilities, as well as engaging electrification in all communities within the urban centers.

\section{Placing National Interest above Personal Interest:}

African leaders need to set examples to their followers (the people, citizenries) on how to place national interests above personal interests. There is great need for re-orientation of the hearts and mind of the African people. Some of the reasons why the people fight the government are when they see a government that does not yield to the aspiration of the people. This can also be examined in African countries where the leaders want to remain in power till their death.

\section{REFERENCES}

\section{Articles}

[1]. Adeleke, A. (1995). The Politics and Diplomacy of Peacekeeping in West Africa: The ECOWAS Operation in Liberia. The Journal of Modern African Studies, 33(04), 569-593.

[2]. Ademowo, A. J. (2015). Boko Haram Insurgency and the Imperative of Promoting a Culture of Peace in Nigeria.The International Journal of Business \& Management, 3(8), 224.

[3]. Adibe, C. E. (1997). The Liberian conflict and the ECOWAS-UN partnership.Third World Quarterly, 18(3), 471-488.

[4]. Agbiboa, D. E. (2013). Why Boko Haram exists: The relative deprivation perspective. African Conflict \& Peacebuilding Review, 3(1), 144-157.

[5]. Agbiboa, D. E., \&Maiangwa, B. (2013). Boko Haram, Religious Violence, and the Crisis of National Identity in Nigeria: Towards a Non-killing Approach. Journal of Developing Societies, 29(4), 379-403.

[6]. Aliyu, F. A. (2013). Rhetoric and political leadership: a practitioner's reflection: practitioners' notes. African Journal of Rhetoric, 5(1), 181-195.

[7]. Awopeju, A., Adelusi, O., \&Oluwashakin, A. (2012).Zoning formula and the party politics in Nigerian democracy: A crossroad for PDP in 2015 presidential election.Research on Humanities and Social Sciences, 2(4), 11-19. Bah, A. B. (2010). Democracy and civil war: Citizenship and peacemaking in Côte d'Ivoire. African Affairs, 109(437), 597-615.

[8]. Ezeibe, C., Abada, I., \&Okeke, M. (2016).Zoning of Public Offices, Liberal Democracy and Economic Development in Nigeria.Mediterranean Journal of Social Sciences, 7(3 S1), 328

[9]. Francis, D. J. (2009). Peacekeeping in a bad neighbourhood: The Economic Community of West African States (ECOWAS) in peace and security in West Africa. African Journal on Conflict Resolution, 9(3)

[10]. Gershoni, Y. (1997). War without end and an end to a war: the prolonged wars in Liberia and Sierra Leone. African Studies Review, 40(03), 55-76.

[11]. Inegbedion, E. J. (1994). ECOMOG in Comparative Perspective.In The Political Economy of Foreign Policy in ECOWAS (pp. 218-244).Palgrave Macmillan UK.

[12]. Ofuatey-Kodjoe, W. (1994). Regional organizations and the resolution of internal conflict: The ECOWAS intervention in Liberia. International Peacekeeping, 1(3), 261-302.

[13]. Ololajulo, B. O. (2016). 'Eating with One Spoon': Zoning, Power Rotation and Political Corruption in Nigeria. African Studies, 75(1), 153-169.

[14]. Onapajo, H., Uzodike, U. O., \&Whetho, A. (2012). Boko Haram terrorism in Nigeria: The international dimension. South African Journal of International Affairs, 19(3), 337-357.

[15]. Onuoha, F. C. (2014). A Danger Not to Nigeria Alone: Boko Harams's Transnational Reach and Regional Responses. Friedrich-Ebert-Stiftung Regional Office.

[16]. Oshewolo, S. (2013).A Reconsideration of the Ethno-Religious Dimensions to Nigeria's 2011 Presidential Election.

[17]. Tarr, S. B. (1993). The ECOMOG Initiative in Liberia: A Liberian Perspective. Issue, 21(1-2), 74-83.

[18]. Terwase, I. T., Abdul-Talib, A. N. \& Zengeni, K. T. (2015) Conflict Resolution: the Truncated Zoning Arrangement and the Buhari Political Tsunami in Nigeria.Journal of Government and Politics, Vol.6 No. 2. 248-259

[19]. Terwase, I. T., Abdul-Talib, A. N. \& Zengeni, K. T. (2015) The Role of ECOWAS on Economic Governance, Peace and Security Perspectives in West Africa. Mediterranean Journal of Social Sciences, Vol. 6, No. 3, 257-261

[20]. Terwase, I. T., Yerima, H. M., Abdul-Talib, A. N., \& Ibrahim, M. B. (2016). The Issues behind Agitations, Conflict and War: A Case of Nigeria. International Review of Management and Marketing, 6(7S).

[21]. Udounwa, S. E. (2013). Boko Haram: Developing New Strategies to Combat Terrorism in Nigeria. ARMY WAR COLLEGE CARLISLE BARRACKS PA. 


\section{Websites}

[1]. The Guardian, 21 December, (2016) Gambian president YahyaJammeh says he will not step down Retrieved from https://www.theguardian.com/world/2016/dec/21/gambia-president-yahya-jammeh-will-not-step-down

[2]. The Guardian, 21 January, (2017)YahyaJammeh leaves the Gambia after 22 years of rule. Retrieved fromhttps://www.theguardian.com/world/2017/jan/21/anxious-gambians-await-former-president-yahya-jammehdeparture 